\title{
Characterization of Indigenous Rhizobacterial Isolates from Healthy Chilli Rhizosphere Capable of Inducing Resistance Against Anthracnose Disease (Colletotrichum Gloeosporioides).
}

\author{
Fatimah $^{\#}$. T. Habazar, D. Arbain, Nurbailis* \\ ${ }^{\#}$ Faculty of Agriculture, Tamansiswa University, Padang, West Sumatera; \\ E-mail : Anisfatimah70@Yahoo.com \\ *Andalas University, Padang, West Sumatera, Indonesia
}

\begin{abstract}
Antrachnose disease on chilli caused by Colletotrichum gloeosporioides is difficult to be controlled because the disease can be transmitted through the seeds, and has a high genetic diversity. One of promising alternative control is using biological control agents, such as groups of rhizobacteria. The objective of this research were : to characterize the morphology, physiology and molecular of selected rhizobacterial isolates, which were capable of controlling the anthracnose disease and to enhance the growth and yield chilli. Three rhizobacterial isolates (B1.37, B2.11 and P1.31) were used. These isolates were indentified based on morphology (colony form, elevation, edge, and color), physiology (gram tes, the production of hormone IAA, chitinase enzyme, hydrogen cyanide, and solvents phosphate) and molecular. The isolates were identified by using $16 \mathrm{~S}$ rRNA sequencing. The results indicated that isolate B1.37 belonged to species of Bacillus cereus strain ML 267, isolate B2.11 belonged to Bacillus cereus strain LH8 and isolate P1.31 belonged to Chryseobacterium gleum strain NBRC 15054.
\end{abstract}

Keywords — Morphology, physiology, molecular, rhizobacteria, anthracnose, chilli

\section{INTRODUCTION}

Introductions of indigenous rhizobacterial $(\mathrm{RB})$ isolates from West Sumatera can induce systemic resistance on chilli against anthracnose disease in the field. B1.37 and $\mathrm{P} 1.31$ is the best isolates in increasing resistance on chilli plants. Introductions of indigenus rhizobacterial isolates on chilli seeds is an effort to obtain a source of healthy plants to face the complexity of problems by the plants after being transferred to an endemic areas. Mechanisms of induced systemic resistance of plants by bacteria isolates generally involve production of bacterial metabolites such as : hydrogen cyanide ( $\mathrm{HCN})$, extracellular lytic enzmes (chitinase), dissolved phosphate [1] and [2] , and to produce indole acetic acid (IAA) growth hormone by bacteria isolates for stimulate plant vigor and more able to resist the attack of pathogens [2]. Until now there have not been a report on the ability of indigenous rhizobacterial isolates to control anthracnose disease and enhance the growth of chili seedlings, physiological responses of induced systemic resistance of chilli plants and morphological, physiological and molecular characterization. The objectives of this research were: to characterize the morphology, physiology and molecular of selected rhizobacterial isolates, which have the ability to control the anthracnose disease and to enhance the growth and yield of chilli.

\section{MATERIALS AND METHODS.}

Research consisted of 2 stages, 1) Characterization of morphology and physiology of indigenous RB isolates, conducted in Laboratory of Biotechnology Department, College of Agriculture and Laboratory of Natural Products Chemichal, Faculty of Pharmacy, Andalas University. 2) Molecular identification of indigenous RB isolates, conducted in laboratory of biogenetic research station in Bogor, from January to October 2013.

Materials used in this experiment were: NA media, Kings B media, TSA media, peptin media, TSB (Trypic Soya Broth) media, CDS solution (cyanide Detection Solution), Picric acid, sodium carbonate, distilled water sterile, phosphate buffer $0.1 \mathrm{~N}, 3 \% \mathrm{KOH}, 1 \mathrm{~N} \mathrm{HCL}, \mathrm{HCL}_{3}$, IAA, alcohol, spirits, namely random primer P5 (5 'AACGCGCAAC-3'), TE, SDS, proteinnase K, CTAB/ $\mathrm{NaCl}$, phenol : chloroform: isoamyl-alcohol (PCL), agarose gel, sodium acetate isopropanol, tag polymerase, Tris- $\mathrm{HCl}, \mathrm{KCl}$, $\mathrm{MgCl}_{2}$, dNTPs, buffer TBE, etc. The tools used include : a 
glass cup, erlemeyer, glass objects, petri dishes, test tubes, needles ose, filter paper, measuring cup, measuring pipette, autoclave, laminar air flow, Bunsen lamp, UV transluminator, kauntor colony, homogenizer, spectrophotometers, PCR machines, analytical balance, pipette, heating plate, and stationery.

\section{Working procedure:}

\section{A.Characterization of morphology and physiology of} indigenous $R B$ isolates

Characterization of morphology of indigenus RB isolates : Bacteria were cultured in media Trytic Soya Agar (TSA) for Bacillus group and Nutrient Agar (NA) for the other groups. They were incubated for two days and observed. Observation covered, color, form, elevation, and diameter of the colony [3].

\section{B. Characterization of physiology of indigenous $R B$ isolates}

Gram test: The purpose of doing gram test is to determine whether the reaction of the bacteria isolates are gram negative or positive. One ose of bacterial culture $(2 \mathrm{x}$ 24 hours old) was taken and placed on object glass, then was dripped by one drop of $\mathrm{KOH}$ solution (3\%). If clumping occurs, the bacteria is gram-negative and if not it is grampositive bacteria [4].

Production of IAA growth hormone : To produce IAA growth hormone the procedure used was the one described by [5]. Rhizobacteria isolates were grown in King's B liquid medium, added with $5 \mathrm{ml}$ solution of tryptophan $(0.5 \%)$ and without solution of tryptophan. Bacterial cells were grown in erlemeyer $(100 \mathrm{ml})$ and were placed on shaker $(120 \mathrm{rpm})$ for 2 days at $30^{\circ} \mathrm{C}$. After incubation, the cells were centrifuged (3.000 rpm for $10 \mathrm{~min}$ at $4^{0} \mathrm{C}$ ) and $1 \mathrm{ml}$ of supernatant was combined with $2 \mathrm{ml}$ of Salkowsky reagent $(150 \mathrm{ml}$ of 95 $98 \% \mathrm{H}_{2} \mathrm{SO} 4,7,5 \mathrm{ml}$ of $0,5 \mathrm{M} \mathrm{FeCl} / 6 \mathrm{H}_{2} \mathrm{O}$, and $250 \mathrm{ml}$ distilled water) and incubated for $30 \mathrm{~min}$ at room temperature. The quantification of IAA was carried out using IAA standard curve.

Production of chitinase enzyme : Production of chitinase enzyme qualitatively was evaluated by observing the formation of clear zone around the bacteria described by [6]. Rhizobacteria isolates were grown in medium containing coloidal chitin. Composition of the medium was : $\mathrm{Na}_{2} \mathrm{HPO}_{4}$ (0.65), $\mathrm{KH}_{2} \mathrm{PO}_{4}$ (1.5), $\mathrm{NaCL}(0.25), \mathrm{NH}_{4} \mathrm{Cl}(0.5), \mathrm{MgSO}_{4}$ (0.12), $\mathrm{CaCl}_{2}$ (0.005), colloidal chitin (10), $\mathrm{pH} 6.5$, and agar (15) in $\left(\mathrm{g} \mathrm{L}^{-1)}\right.$. Sterilized medium was poured into petri dishes and allowed it to freeze. Bacterial isolates to be tested were taken a little bit and scratched into the media and then incubated for 10 days at a temperature of $30^{\circ} \mathrm{C}$. Parameters measured were colony and clear zone diameter. The ratio of chitinase enzyme activity was determined by comparing size of the clear zone (CZ) and the colony size (CS) [7].

Phosphate Solvents : The ability to dilute phosphate qualitatively was evaluated by observing the formation of clear zone around the bacteria. Rhizbacteria isolates were grown in selective Pikovskaya medium described by [8] with omposition of the medium used was : $10 \mathrm{~g} / \mathrm{L}$ glucose, $5 \mathrm{~g} / \mathrm{L}$ $\mathrm{Ca}_{3} \mathrm{PO}_{4}, 0.5 \mathrm{~g} / \mathrm{L} \quad\left(\mathrm{NH}_{4}\right)_{2} \mathrm{SO}_{4}, 0.2 \mathrm{~g} / \mathrm{L} \quad \mathrm{KCl}, 0,1 \mathrm{~g} / \mathrm{L}$ $\mathrm{MgSO}_{4} .7 \mathrm{H} 2 \mathrm{O}, 0.01 \mathrm{~g} / \mathrm{L} \quad \mathrm{MnSO}_{4} \cdot \mathrm{H}_{2} \mathrm{O}, 0.5 \mathrm{~g} / \mathrm{L}$ of yeast extract and $0.01 \mathrm{~g} / \mathrm{L} \mathrm{FeCl}_{3} .6 \mathrm{H} 2 \mathrm{O}$, and $15 \mathrm{~g}$ agar/L at $\mathrm{pH} 7.0$. Sterilized medium was poured into petri dishes and allow them to freeze. Bacterial isolates to be tested were then taken a little bit and scratched into the media and incubated for 5 days at a temperature of $30^{\circ} \mathrm{C}$. Parameters measured were colony and clear zone diameter. The ratio of phosphate solvents activity was determined by comparing size of the clear zone (CZ) and the colony size (CS) [7].

Production of hydrogen cyanide $(\mathrm{HCN})$ : To produce hydrogen cyanide qualitatively method of Bakker and Schiper (Munif, 2001) was used. Composition of the medium used was $4.4 \mathrm{~g}$ glycine; $30 \mathrm{~g}$ Trytic Soy Broth (TSB); $15 \mathrm{~g}$ of agar in $1000 \mathrm{ml}$ in distilled water. Medium was sterilized by autoclaving for 20 minutes. Medium was poured into petri dishes. The production of cyanide was detected using solution of Cyanide Detection Solution (CDS) containing $2 \mathrm{~g}$ of picric acid and $8 \mathrm{~g}$ of sodium carbonate, and then dissolved in $200 \mathrm{ml}$ of sterile distilled water. Filter paper was cut into size of $1 \times 1 \mathrm{~cm}^{2}$ and sterilized. Pieces of filter paper were dipped in solution CDS and placed at upperside of the petri dish lid, and then incubated at room temperature for 4 days. Bacteria producing hydrogen cyanide was detected by a change in color from yellow to brownish orange on the filter paper.

\section{Molecular identfication of indigenous RB isolates}

Isolation of DNA: Indigenous RB isolates to be isolated DNA were grown in NB medium for 48 hours. Bacterial cells are harvested by means of sentrifigasi culture, $1.5 \mathrm{ml}$ of culture at $15.000 \mathrm{rpm}$ for 10-15 minutes. Suspended pelet in $200 \mu 1 \mathrm{TE}$ using vortex. Add $50 \mu 1$ SDS (19\%) and stirred by means of reversing the tube several times until the suspension looks clear. Add $10 \mu \mathrm{l}$ proteinase $\mathrm{K}(10 \mathrm{mg} / \mathrm{mL})$ and incubated at $37^{\circ} \mathrm{C}$ (in water bath) for 1 hour. Add $80 \mu \mathrm{L}$ $\mathrm{CTAB} / \mathrm{NaCl}(10 \% \mathrm{CTAB}$ in $0.7 \mathrm{M} \mathrm{NaCl})$ and incubated at $65^{\circ} \mathrm{C}$ for 20 minutes. Add phenol : chloroform : Isoamyl alcohol $(\mathrm{PCl}) 25: 24: 1$ mixture and do as much volume with vortex mixing for 2 minutes. Centrifugation at $11 \mathrm{rpm}$ for 15 minutes to separate the mixed phase. Move the liquid phase (aqueous phase) to a new tube and add $\mathrm{Cl}$ (24: 1) with the same volume. Performed by vortex mixing for 2 minutes. Then in a centrifuge at a speed of $11 \mathrm{rpm}$ for 15 minutes and take the supernatant transferred to a new tube. Add 0.1 volume of sodium acetate $(1 \mathrm{M})$ and the same volume of isopropanol, mix by reversing the tube several times. Discard the ethanol and dry the pellet with vacum for approximately 15 minutes. Pellet suspended in $100 \mu 1 \mathrm{TE}$ or sterile distilled water [10].

DNA amplification and sequence analysis : Extracted DNA was amplified by PCR based method of [10] using a random primer that P5 (5'-AACGCGCAAC-3 '), each PCR reaction $(25 \mu 1)$ consists of $5 \mu$ l DNA template, $1 \mu 1$ random primer $(10 \mu \mathrm{M})$, Tag polymerase, $10 \mathrm{mM}$ Tris- $\mathrm{HCl}(\mathrm{pH} 9.0)$, $50 \mathrm{mM} \mathrm{KCl}, 3 \mathrm{mM} \mathrm{MgCl} 2$, each dNTP $400 \mu \mathrm{M}$ (Amersham Pharmacia Biotech). DNA amplifikasi at a temperature of $92^{\circ} \mathrm{C}$ for $1 \mathrm{~min}$, primer placement at a temperature of $35^{\circ} \mathrm{C}$ for 1 min and DNA synthesis at $73^{0} \mathrm{C}$ for 2 minutes. 


\section{RESULTS AND DISCUSSION}

\section{A. Characterization of the morphology and physiology of indigenous $R B$ isolates}

Characterization of the morphology and physiology of indigenous RB Isolates: Observation of indigenous RB isolates indicated that all isolates showed colony with beige color, isolate B1.37 was gram-positive, convex elevation, reguler form, a rod shape, diameter $1.5 \mathrm{~mm}$. Isolate B2.11 was gram-positive, flat elevation, irregular form, diameter 3 $\mathrm{mm}$. Isolate P1.31 was gram-negative, flat elevation, irregular form, and diameter $5 \mathrm{~mm}$ (Table 1).

TABLE I

CHARACTERIZATION OF MORPHOLOGICAL AND PHYSIOLOGICAL

\begin{tabular}{|c|c|c|c|c|c|c|c|}
\hline \multirow[t]{2}{*}{ No } & \multicolumn{2}{|c|}{$\begin{array}{c}\text { Indigenus } \\
\mathrm{RB} \text { isolates }\end{array}$} & \multicolumn{5}{|c|}{ Colony of indigenous RB isolates } \\
\hline & $\begin{array}{l}\text { co } \\
\text { de }\end{array}$ & Origin & $\begin{array}{l}\text { Natu } \\
\text { re }\end{array}$ & Color & Form & $\begin{array}{l}\text { Elevati } \\
\text { on }\end{array}$ & $\begin{array}{l}\text { Diameter } \\
(\mathrm{mm})\end{array}$ \\
\hline 1 & $\begin{array}{l}\text { B1 } \\
.37\end{array}$ & $\begin{array}{l}\text { Highla } \\
\text { nd }\end{array}$ & $\begin{array}{l}\text { Gra } \\
\mathrm{m}+\end{array}$ & $\begin{array}{l}\text { Beig } \\
\mathrm{e}\end{array}$ & $\begin{array}{l}\text { Regu } \\
\text { ler }\end{array}$ & $\begin{array}{l}\text { Conve } \\
\mathrm{x}\end{array}$ & 1,5 \\
\hline 2 & $\begin{array}{l}\text { P1. } \\
31\end{array}$ & $\begin{array}{l}\text { Lowlan } \\
\text { d }\end{array}$ & $\begin{array}{l}\text { Gra } \\
\mathrm{m}-\end{array}$ & $\begin{array}{l}\text { Beig } \\
\mathrm{e}\end{array}$ & $\begin{array}{l}\text { Irreg } \\
\text { uler }\end{array}$ & Flat & 5 \\
\hline 3 & $\begin{array}{l}\mathrm{B} 2 \\
.11\end{array}$ & $\begin{array}{l}\text { Highla } \\
\text { nd }\end{array}$ & $\begin{array}{l}\text { Gra } \\
\mathrm{m}+\end{array}$ & $\begin{array}{l}\text { Beig } \\
e\end{array}$ & $\begin{array}{l}\text { Irreg } \\
\text { uler }\end{array}$ & Flat & 3 \\
\hline
\end{tabular}

\section{B. Characterization of physiology of indigenous $R B$ isolates.}

Production of IAA growth hormone : Isolates P1.31 and B1.37 capable of producing IAA growth hormone approximately $11.6 \mu \mathrm{g} / \mathrm{mL}$ and $15.7 \mu \mathrm{g} / \mathrm{mL}$, when compared with pured IAA solution. Isolate B2.11 did not produce IAA growth hormone. For more details the production of IAA growth hormone by indigenous $\mathrm{RB}$ isolates could be seen in Fig. 1.

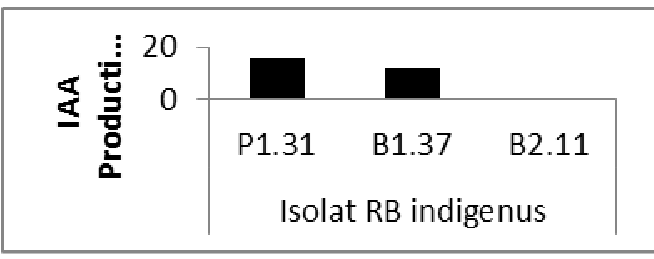

Fig. 1. Production of IAA hormones by indigenous RB isolates

Figure 1 showed that the indigenous $\mathrm{RB}$ isolates were capable of producing IAA growth hormone $11.6 \mu \mathrm{g} / \mathrm{mL}$ $15.7 \mu \mathrm{g} / \mathrm{mL}$. IAA growth hormone served to accelerate and affect root growth of chilli plants, so as to meet the need of nutrients and water, and lead to changes in the chemical compounds in plants, and stimulate plant vigor and more able to resist the attack of pathogen.

[11] suggested that Pseudomonas fluorescens bacteria not only increase the availability of phosphate but also able to produce growth regulating substances such as indole acetic acid (IAA) and gibberellin acid (GA3) and vitamins, IAA hormones acts as a plant growth promoter, causing plants to be healthy, strong and resistant to pathogen attack. [12] obtained endophytic bacteria from the roots and seeds of corn that capable of synthesizing IAA hormones and able to induce systemic resistance by suppressing wilt stewart disease severity on corn plants ranging from 48.95 to
$55.60 \%$. [13] obtained IAA hormone produced by PGPR from isolates of Pseudomonas fluorescens 89B61, Serratia marcescesn 90-166, Bacillus pumilus SE34, Pseudomonas chlororaphis $\mathrm{O} 6$ and the gacS mutant, in triptopan medium and Salkowski reagents respectively $34 \mu \mathrm{g} / \mathrm{mL}, 25 \mu \mathrm{g} / \mathrm{mL}$, $7,5 \mu \mathrm{g} / \mathrm{mL}, 5 \mu \mathrm{g} / \mathrm{mL}, 35 \mu \mathrm{g} / \mathrm{mL}$.

According to [14] the success of the biological control of plant diseases is determined by the mechanism of inhibition against pathogenic biological control agents. The mechanism of inhibition of every different biological agents, and each can have more than one mechanism of inhibition. Wide inhibitory mechanism that is generally found in biological agents is siderophores, antibiosis, competition, micoparasitisme, PGPR, induced resistance, enzymes and toxins. Each mechanism of inhibition of these plants have special characteristics as well as the nature and involves several factors that influence it.

Production of chitinase enzyme : All bacterial isolates produced clearing zones. [6] classified producers as good when $\mathrm{CZ} / \mathrm{CS}>2$ and weak when $\mathrm{CZ} / \mathrm{CS}<2$ (Tabel 2).

TABLE II

RATIO OF CZ/CS OF VARIOUS ISOLATES

\begin{tabular}{|c|c|c|c|}
\hline No & $\begin{array}{c}\text { The indigenous } \\
\text { RB isolates }\end{array}$ & $\begin{array}{c}\text { CZ/C } \\
\text { S }\end{array}$ & Producers \\
\hline 1 & $\mathrm{~B} 2.11$ & 2.1 & Good \\
\hline 2 & $\mathrm{~B} 1.37$ & 1,6 & Weak \\
\hline 3 & $\mathrm{P} 1.31$ & 1,6 & Weak \\
\hline
\end{tabular}

Table 2 showed that isolates $\mathrm{B} 2.11$ had a highest $\mathrm{CZ} / \mathrm{CS}$ ratio, 2.1 followed by isolate $\mathrm{B} 1.37$ and isolate $\mathrm{P} 1.31$. High ratio of $\mathrm{CZ} / \mathrm{CS}$ indicates an isolate has higher ability for degradation. [6] found 18 isolates of rizobacteria producing CZ/CS ratio approximately 1,11 to 2,50 grown in medium of chitin agar. This was consistent with the finding of [1] that PfMDU3 PfMDU2 isolates capable of producing the enzyme chitinase with clear zone of $2.2 \mathrm{~mm}$ wide on a medium containing $0.2 \%$ coloidal chitin, and was able to inhibit the mycelial growth of Rhizoctonia solani causing stem rot disease on rice plants in vitro.

The chitinase enzyme is an enzyme that can degrade chitin. Chitin is a constituent component of most fungal cell walls. Chitinase produces an extracellular enzyme that is used for making nutrients for bacteria. Chitinase degrades chitin oligomers into simpler compounds making the medium appears clear, especially around the bacterial colonies [15]. Chitin in the medium induces the secretion of chitinase to degrade chitin as a carbon source. [16] obtained chitinase enzyme secreted by Bacillus alvei BG07, BG12 and Bacillus cereus BG 35 capable of controlling the fungus Colletotichum capsici in vitro. In addition [17] also obtained transgenic tobacco plants resistant to Botrytis cinerea fungus due to the expression of $\beta-1,3$ endoglukanase.[17] reported from the study of chitinase enzyme activity using the induction method to diffuse directly, she obtained bacterial isolates having chitinase enzyme activity, with diameter of $1.29 \mathrm{~cm}$, capable of controlling the fungus Candida albicans.

Ability of indigenous $\mathrm{RB}$ isolates to dissolve phosphate Capability of indigenous RB isolates to dissolve phosphate was detected by the formation of a clear zone around the 
bacteria. The results showed that all isolates produced clear zones (Fig. 2). The value of CZ/CS ratio isolates B2.11, $\mathrm{B} 1,37$ and $\mathrm{P} 1.31$ are presented in Table 3.
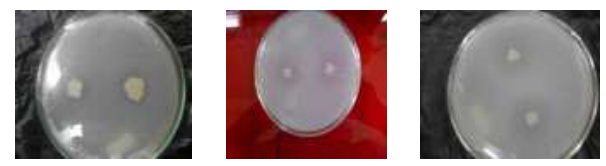

Fig. 2. Clear zone around the indigenous RB isolates

TABLE III

RATIO OF CZ/CS OF VARIOUS ISOLATES

\begin{tabular}{|l|l|l|l|}
\hline No & $\begin{array}{l}\text { the indigenous } \\
\text { RB isolates }\end{array}$ & CZ/CS & Producers \\
\hline 1 & B2.11 & 2.70 & Good \\
\hline 2 & B1.37 & 2.50 & Good \\
\hline 3 & P1.31 & 1.25 & Weak \\
\hline
\end{tabular}

Table 3 showed that indigenous RB isolate B2.11 had a highest $\mathrm{CZ} / \mathrm{CS}$ ratio, 2.70, followed isolate $\mathrm{B} 1.37$ with of $\mathrm{CZ} / \mathrm{CS}$ ratio is 2,50 and isolate $\mathrm{P} 1.31$ with of $\mathrm{CZ} / \mathrm{CS}$ ratio is 1,25. [18] obtained the genus Streptomyces, Stretosporangium, Nocardia and Microtetraspora having the ability to dissolve phosphate with ratio CZ / CS ranged from 0.78 to 3 .

Dissolution of phosphate is caused by organic acids of non-volatile produced by microbes. These acids derive from metabolism of glucose as a carbon source. According to [19] organic acids produced by bacteria include: citric acid, glutamic acid, Succinic, lactic, oxalic, glyoxylic, malate and fumarate. The organic acid will chelate cations in the form of a stable complex with $\mathrm{Ca} 2+, \mathrm{Mg} 2+, \mathrm{Fe} 2+$ and $\mathrm{Al} 3+$, resulting in a solvent phosphate into available forms that can be absorbed by plants.

Production of hydrogen cyanide : Production of hydrogen cyanide was detected by discoloration of filter paper containing solution of CyanideDetection Solution from yellow to orange. The result showed that three isolates did not show the change of filter paper color, meaning that indigenus RB isolates did not produce hydrogen cyanide, and antagonistic compounds against Colletotrichum capsici. According to [20] P.fluorescens strains used to trigger plant growth and pathogen control, with a variety of mechanisms including production of siderophores, hydrogen cyanide, and antibiosis.

\section{Molecular identification of indigenous $R B$ isolates}

Molecular identification of indigenous RB isolates based $16 \mathrm{~S}$ rRNA gene sequences, known isolate B1.37 is $100 \%$ similar with Bacillus cereus strain ML 267, isolate B2.11 is 99\% similar to the Bacillus cereus strain LH8, and isolate P1.31 is $99 \%$ similar to the Chryseobacterium gleum strain NBRC 15054. [21] reported Bacillus cereus is a type rizobakteria which includes division Firmicutes, class Firmibacteria, Bacillales order, family Bacillaceae. These bacteria are characterized as gram-positive, rod shape, onecelled, sized (0.5-2.5) x (1.2 to 10) $\mu \mathrm{m}$, aerobic or facultative anaerobic and heterotrophic, more heat resistant, dry and other environmental factors destructive. These bacteria can survive in a certain environment that can survive at temperatures of -5 to $75^{\circ} \mathrm{C}$ with the level of acidity $(\mathrm{pH})$ between 2-8. [22] obtained six rizobakteria strains that are PGPR (Plant Growth Promoting Rizobacteria) from the Bacillus group: Bacillus pumilus 4, B.pumilus IN7R, B.amyloliquefaciens IN937a, B.subtilis IN937b, B.pumilus SE34, and B. subtilis GB05 able to induce plant resistance of wheat (Pennisatum glaucum) against Powdery mildew diseases (powdery mildew) by Sclerotium graminicola. Furthermore, [23] reported Chryseobacterium gleum, are gram-negative, aerobic, rod shape. [24] obtained that isolate Chryseobacterium sp strains StRB 126 isolated from the roots on potato plant have the ability to produce enzymes for degradation.

\section{CONCLUTION}

Based on the experimental results it can be concluded that isolate B1.37 was identified as Bacillus cereus strain ML 267, isolate B2.11 was identified as Bacillus cereus strains LH8 and isolate P1.31 was identified as Chryseobacterium gleum strain NBRC 15054. All rizobacterial isolates capable of producing chitinase enzyme, phosphate solvent but not capable of producing hydrogen cyanide. Bacillus cereus strain ML 267 and Chryseobacterium gleum strains NBRC 15054 capable of producing indole acetid acid (IAA) growth hormone, while Bacillus cereus strains LH8 did not produce IAA growth hormone.

\section{ACKNOWLEDGMENT}

I would like to thank to my advisors for correct this papper to publish in International Journal on Advanced Science, Engineering and Information Technology (IJASEIT).

\section{REFERENCES}

[1] Nagarajkumar, M., R.Bhaskaran., and R. Velazhahan.. Involment of secondary metaboles and extracelluler lytic enzymes produced by Psedomonas fluorescens in hibition of Rhizoctonia solani, the rice sheath blight pathogen. Microbiological Research. Departement of plant Pathology, College and Research Institute, Tamil Nadu Agricultural University Madural 625104, Tamil Nadu, India. 2004

[2] Habazar, T., Trizelia dan Y. Yanti.. Protection of plant biotechnology. Andalas University Press. 2010

[3] Cowan, M.K and K.P. Talaro. Microbiology A Systems Approach. McGraw-Hill Companies. New York. 2006.

[4] Faramarzi,M.A., M. Fazeli., M.T. Yazdi., S.Adrangi., K.J. Al Ahmadi. Optimization of Cultural Condition for Production of Chitinase by aSoil Isolate of Massilia timonae. Biotechnology Reseach Center, Departement of Pharmaceutical Biotechnology, Faculty of Pharma. Tehran University of Medical Science. 2008.

[5] Purwaningsih, S. Isolation, Population and Characterization of Bacterial Phosphate Solvents in Soil of National Park Bogani Nani Wartabone, North Sulawesi, Biology. Vol 3, pp. 22-31, 2003.

[6] Pelczar, J.M and Chan. E.C.S. Fundamentals of Microbiology. UI Press. Jakarta. Vol 2, pp 34-38, 2006

[7] Klement., Z., Rodolph,K., and Sands, D.C. Methods in Phytobacteriology. Academiai.Kiado.Buddapest. 1990.

[8] Patten, C., Glick,B. Role of Pseudomonas putida indole acid in evelopment of the host plant root system. Applied and Enviromental Microbiology. Vol.68, pp. 3795-3801. 2002.

[9] Munif, A. Studies on the importance of Endophytic Bacteria for the Biological Control of the Root-knot Nematode Meloidogyne incognita on Tomato (Dissertation). Bonn, Germany : Intitute for Plant Disease, University of Bonn. 2001.

[10] Jamsari. Biotechnology Beginners. Basic principles and application of molecular analysis. UNRI Press. 2007. 
[11] Shilev, S., A.F.Lopez,M.S.Pri eto and E.D.S.Puebla.. Induced protein profile change inarsenate tolerant and sensitive Psedomonas fluorescens strain. J.Environ.Eng.Land, Manag. Vol 25, pp. 221-226. 2007.

[12] Rahma, H. Induction of resistance maize plant against wilt disease stewart (Pantoea stewartii sub sp. Stewartii) using endophytic bacteria. Seminar and National Congress All-XXII of the Association of Indonesian Phytopathology. Padang,2013.

[13] Kang,B.R., K.Y. Yang., B.H. Cho., T.H.Han., I.S.Han.,M.C.Lee. A.J.Anderson and Y.C.Kim. Production of indole-3-acid in the plantbeneficial strain Psedomonas chlororaphis O6 is negatively regulated by the global sensorurrent Microbiology. An International Journal. Vol. 52,. pp.473-476. 2006.

[14] Soesanto, L. Introduction to Biological Control of Plant diseases Supplements to Weeds and Nematodes. Rajawali Press. Rajagrafindo PT Persada. Jakarta.573 p. 2006

[15] Patil, R.S., V.Ghormade and M.V.Deshpande.. Chitinolytic enzymes : An exploration. Enzyme Microbiol. Technol. Vol.26, 473483.2000

[16] Sutariati,G.A.K., Widodo., Sudarsono and Satriyas, I. Physiological Characters and Effectiveness of Rhizobacteria Isolates as Colletotrichum capsici Antagonist Agent and Plant Growth Promothing Rhizobacteria of Hot Pepper. J. Ilmiah Pertanian Kultura. Vol.4, pp. 23-27. 2006.

[17] Manuhara, Y.S.W. Isolasi dan karakterisasi Enzim $\beta-1,3$ endoglukanase dari tanaman kubis (Brassica oleraceae cv.capitata L.). Departemen Biologi, Fakultas Sain dan Teknologi, Universitas Airlangga. Surabaya. 2007.
[18] Nurkanto, A. Identificataion of soil actinomycetes in Bukit Bangkirai fire fores East Kalimantan and its potention as cellulolitic and phosphatasesolubilizing. Biodiversitas Vol. 8,pp 314-319. 2007.

[19] Wulandari, S. Efectifity to dissolve phosphate bacterial Pseudomonas sp glycine plant growth on podzolik soil . J. Natur Indonesia. Vol. 4, pp. 29-35. 2001.

[20] Saikia, R., T.Singh., R. Kumar., J.Srivastara., K.Srivastara., K.Singh and D.K.Arora. Role of Salicilic in Systemic resistance Induced by Pseudomonas fluorescens against Fusarium oxysforum f.sp.ciceri in chikpea. Microbiologycal Research. Vol.258, pp. 2003-213.2003.

[21] Fritze, D. Taxonomy of the Genus Bacillus and Related Genera : The Aeropbic Endospore-forming Bacteria. Phytopath. Vol. 94,pp 12451248. 2004.

[22] Raj, S.N., G. Chaluvaraju, K.N. Amruthesh and H.S. Shetty. Induction of growth promotion and resistance against downy mildew on earl millet (Pennisetum glaucum) by rizobacteria. J. Plant Disease. Vol 87. Pp, 380-384. 2003.

[23] Bellais, S., T. Naas, and P. Nordmann. D. Genetic and Bio Chemical Characterization of CGB-1 anAmbler Class B CarbanemHydrolizing $\beta$-Lactanase from Crhyseobacterium gleum. J. Antimicrob Agents Chemother. Vol. 46,pp. 2791-2796. 2002.

[24] Wang,W.Z., T.Morohoshi., N,Someya dan T, Ikeda. AidC, aNovel $\mathrm{N}$-Acylhomeserine Lactonase from the Potato Root-Associated Cytophaga Flavobacteria-Bacteroides (CFB) Group Bacterium Cryseobacterium sp. Strain StRB126. J. American Society For Microbiology.org. 2012. 